\title{
First case of invasive squamous cell carcinoma in a stoma of a Monti ileovesicostomy
}

\author{
Stephen Reid, MD; ; Abdulaziz Althunayan, MD; ${ }^{*}$ John-Paul Capolicchio, MD; Fadi Brimo, MD; ${ }^{+}$ \\ Wassim Kassouf, MD, FRCSC*
}

"Division of Urology, McGill University, Montreal, QC; 'Department of Pathology, McGill University, Montreal, QC

Cite as: Can Urol Assoc J 2014;8(9-10):e654-6. http://dx.doi.org/10.5489/cuaj.2093 Published online September 9, 2014.

\section{Abstract}

We report a very rare case of invasive squamous cell carcinoma (SCC) in the abdominal stoma of a Monti ileovesicostomy. Our patient underwent an uncomplicated Monti ileovesicostomy at age 16 for a neurogenic bladder. She presented 10 years later with difficulty catheterizing the stoma. A biopsy of peristomal tissue showed moderately differentiated SCC. A cystoscopy did not reveal any bladder tumours or suspicious lesions. A computed tomography $(\mathrm{CT})$ scan of the abdomen and pelvis did not demonstrate metastasis. The patient underwent a complete en bloc resection of the stomal site, the Monti, a partial cuff of bladder, and 2 loops of bowel that were adherent to the Monti. Final pathology revealed pure invasive SCC arising around the stoma and negative surgical margins. Six months later, a follow-up CT scan showed no evidence of malignancy, while a cystoscopy revealed a small erythematous area in the posterior bladder wall. Urinary cytology was positive for SCC. Transurethral resection of the erythematous lesion with random bladder biopsies showed SCC in situ in the erythematous lesion and right lateral bladder wall. Staging workup was negative. The patient subsequently underwent a radical cystectomy and ileal conduit diversion with bilateral pelvic lymph node dissection. Final pathology on cystectomy specimen was SCC in situ without evidence of invasive carcinoma. The patient has remained in remission at the 3-year follow-up.

\section{Introduction}

Urinary diversion is a surgical procedure used in patients with a neurogenic bladder who are unable to catheterize their own urethra. A variety of techniques for urinary diversion based on the Mitrofanoff principle have been employed that use different tubular structures as continent abdominal catheterizable channels constructed between the bladder and the skin. ${ }^{1-6}$ The Monti ileovesicostomy uses a short (1 to $2 \mathrm{~cm}$ ) segment of retubularized ileum as a continent abdominal catheterizable channel, with a stoma placed at the level of the umbilicus, or on the lower abdomen. ${ }^{7-9}$ Adenocarcinoma is a rare and late complication of urinary diversion using isolated gut segments. ${ }^{10}$ To our knowledge, no case of squamous cell carcinoma (SCC) following a Monti ileovesicostomy has been reported. Here, we present a case of a 26-year-old female who developed SCC at her stoma site 10 years following a Monti ileovesicostomy.

\section{Case report}

A 26-year-old woman with myelomeningocele underwent an uncomplicated Monti ileovesicostomy located at the umbilicus at age 16 for a neurogenic bladder. Subsequently, she had a revision of her umbilical stoma for stenosis and several surgical repairs for recurrent parastomal incisional hernias. Ten years following installation of the Monti, the patient presented with difficulty catheterizing the stoma and skin lesions around the stoma (Fig. 1). A biopsy of peristomal granular tissue was taken and showed invasive moderately differentiated keratinizing SCC. A cystoscopy did not reveal any bladder tumors or suspicious lesions. A computed tomography (CT) scan of the abdomen and pelvis did not demonstrate metastasis (Fig. 2). The patient underwent a complete en bloc resection of the stomal site, the Monti, a partial cuff of bladder, and 2 loops of bowel adjacent to the Monti that were adherent and possibly involved. Final pathology revealed a pure keratinizing moderately differentiated SCC arising around the stoma and invading the wall of the adherent small bowel loop with focal involvement of the perivesical adipose tissue. SCC in situ was present along the stomal tract. Surgical margins were negative in all areas including the skin, bladder, peritoneal surface, and small bowel (Fig. 3, parts A, B, C). A follow-up CT scan 6 months later showed no evidence of malignancy. A cystoscopy performed at that time revealed a small erythematous area in 


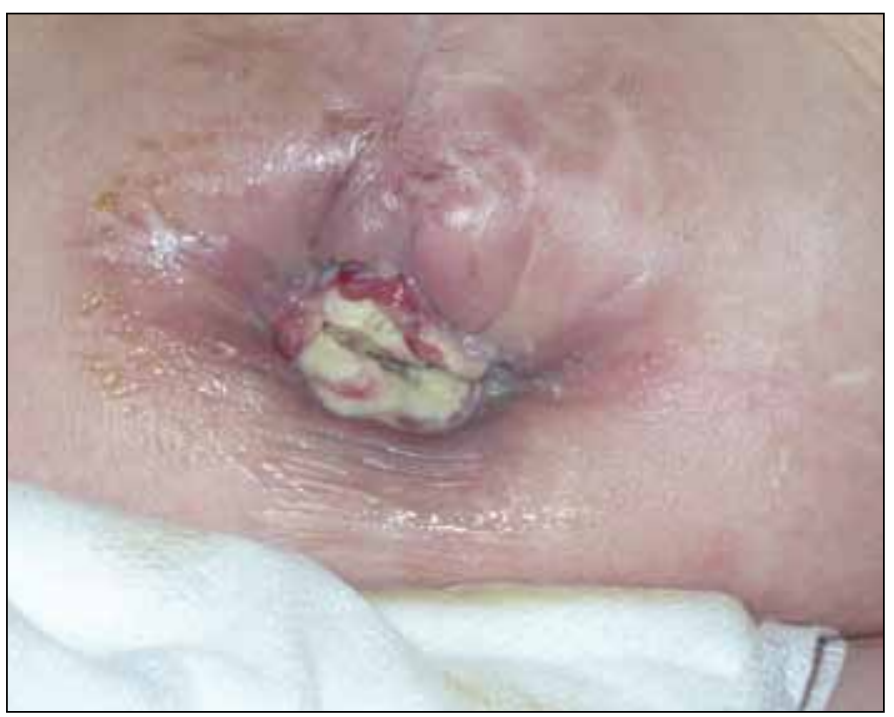

Fig. 1. Photograph of the stomal lesions.

the posterior bladder wall. Urinary cytology was positive for SCC. Transurethral resection of the erythematous lesion with random bladder biopsies was performed showing SCC in situ in the erythematous lesion and right lateral bladder wall. Staging workup was negative. The patient subsequently underwent a radical cystectomy and ileal conduit with bilateral pelvic lymph node dissection. Final pathology revealed SCC in situ without evidence of invasive carcinoma or urothelial lesions (Fig. 3, part D). The patient has remained in remission at the 3-year follow-up.

\section{Discussion}

Chronic inflammation has been shown to be associated with an increased risk of SCC, which includes trauma (catheterizing) and infections. ${ }^{11-15}$ Carcinogenic effects of normal urine and urinary stasis (as in continent diversion) have also been associated with a risk of cancer in bowel segments used for urinary diversion, most commonly adenocarcinoma. Another theory of carcinogenesis has been suggested involving bacterial activation of endogenously formed $\mathrm{N}$-nitrosamine. ${ }^{16-20}$ In this case, it is unclear whether the tumour originated from the skin or the ileum. Given our patient's chronic catheterization, chronic inflammation of the stoma and Monti ileal segment may likely be the predisposing factor for developing squamous metaplasia and SCC in situ. This finding suggests a need to be aware of this complication in patients with urinary diversion, including patients with Monti and other Mitrofanoff procedures. This is the first case report to suggest that SCC may also involve the catheterizable channel. Biopsy of any suspicious lesion around or within a stoma is indicated to rule out malignant transformation and treat in early stage.

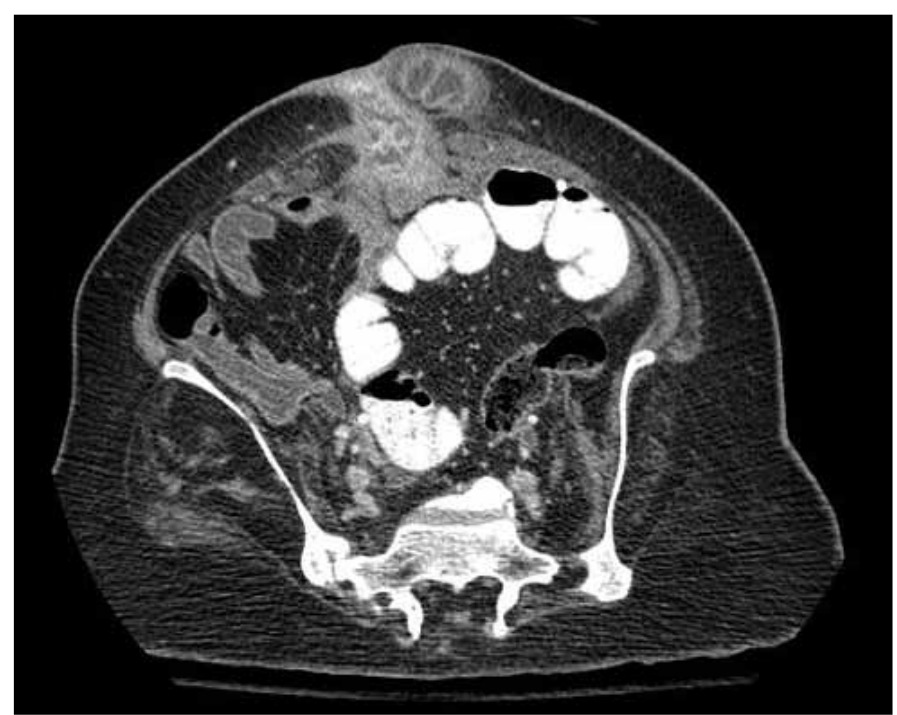

Fig. 2. Image from a computed tomography abdomen demonstrating the mass within the Monti.

\section{Conclusion}

Malignant transformation of bowel segments used in urinary diversion is a known complication of this procedure, and can include catheterizable channels of bowel, such as the Monti. This should be considered when stomal lesions develop or if there is difficulty in the catheterization.

Acknowledgement: Dr. Wassim Kassouf is a recipient of a Research Scholar Award from the FRSQ (Fonds de recherche du Québec - Santé).

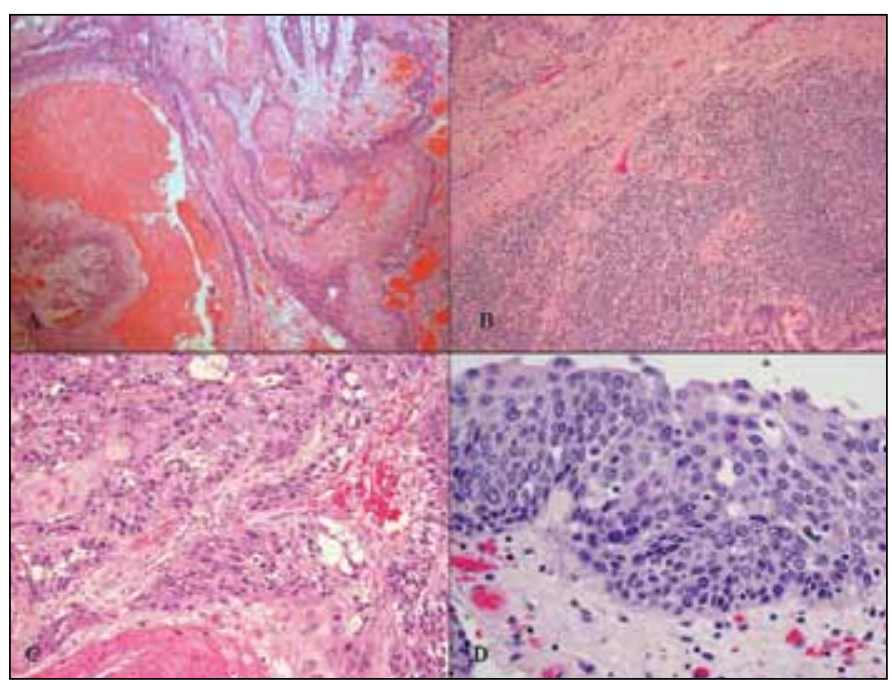

Fig. 3. A. Invasive squamous cell carcinoma (SCC) arising around the stoma and deeply invading the surrounding soft tissue (hematoxylin and eosin stain [H\&E], original magnification 4x); B. SCC focally invading the perivesical adipose tissue and the wall of the small bowel (H\&E, original magnification 10x); C. Keratinizing moderately differentiated invasive SCC (H\&E, original magnification 20x); D. SCC in situ of the bladder (H\&E, original magnification $40 \times)$. 
Reid et al.

Competing interests: Dr. Reid, Dr. Althunayan, Dr. Capolicchio and Dr. Brimo all declare no competing financial or personal interests. Dr. Kassouf is an Advisory Board member and a speaker for Amgen and Astellas. He has also received grants and honoraria from these companies. He is currently participating in unpaid clinical trials.

This paper has been peer-reviewed.

\section{References}

1. Mitrofanoff P. Trans-appendicular continent cystostomy in the management of the neurogenic bladder. Chir Pediatr 1980;21:297-305.

2. Kaefer $M$, Retik $A B$. The Mitrofanoff principle in continent urinary reconstruction. Urol Clin North Am 1997;24:795-811. http://dx.doi.org/10.1016/S0094-0143(05)70421-3

3. Woodhouse CR, MacNeily AE. The Mitrofanoff principle: expanding upon a versatile technique. Br J Urol 1994;74:447-53. http://dx.doi.org/10.1111/i.1464-410X.1994.tb00421.x

4. Bihrle R, Klee LW, Adams MC, et al. Early clinical experience with the transverse colon-gastric tube continent urinary reservoir. J Urol 1991;146:751-3.

5. Adams MC, Bihrle R, Foster RS, et al. Conversion of an ileal conduit to a continent catheterizable stoma. J Urol 1992;147:126-8.

6. Yang WH. Yang needle tunneling technique in creating antireflux and continent mechanisms. I Urol 1993:150:830-4

7. Cain MP, Casale AJ, King SJ, et al. Appendicovesicostomy and newer alternatives for the Mitrofanoff procedure: Results in the last 100 patients at Riley Children's Hospital. J Urol 1999;162:1749-52. http://dx.doi.org/10.1016/S0022-5347(05)68230-4

8. Cain MP, Casale AJ, Rink RC. Initial experience using a catheterizable ileovesicostomy (Monti procedure) in children. Urology 1998;52:870-3. http://dx.doi.org/10.1016/S0090-4295(98)00301-X
9. Monti PR, Lara RC, Dutra MA, et al. New techniques for construction of efferent conduits based on the Mitrofanoff principle. Urology 1997;49:112-5. http://dx.doi.org/10.1016/S0090-4295(96)00503-1

10. Austen M, Kalble T. Secondary malignancies in different forms of urinary diversion using isolated gut. J Urol 2004;172:831-8. http://dx.doi.org/10.1097/01.ju.0000134890.07434.8e

11. Filmer RB, Spencer JR. Malignancies in bladder augmentations and intestinal conduits. J Urol 1990;143:671-8.

12. Gepi-Attee $\mathrm{S}$, Ganabathi K, Abrams PH, et al. Villous adenoma in augmentation colocystoplasty: A case report and discussion of the pathogenesis. J Urol 1992; 147:128-30.

13. Gregoire M, Kantoff P, DeWolf WC. Synchronous adenocarcinoma and transitional cell carcinoma of the bladder associated with augmentation: Case report and review of the literature. J Urol 1993;149:115-8.

14. Tellez Martinez-Fornes M, Burgos Revilla FJ, Del Hoyo Campos J, et al. Metastasizing adenocarcinoma of the colon in a patient with ceco-cystoplasty. Actas Urol Esp 1993;17:80-3.

15. Parenti A, Aragona $F$, Bortuzzo $G$, et al. Abnormal patterns of mucin secretion in ileal neobladder mucosa: Evidence of preneoplastic lesion? Eur Urol 1999;35:98-101. http://dx.doi.org/10.1159/000019826

16. Crissey MM, Steele GD, Gittes RF. Rat model for carcinogenesis in ureterosigmoidostomy. Science 1980;207:1079-80. http://dx.doi.org/10.1126/science.7355272

17. Babaya K, Izumi K, Ozono S, et al. Capability of urinary components to enhance ornithine decarboxylase activity and promote urothelial tumorigenicity. Cancer Res 1983:43:1774-82.

18. Daher $\mathrm{N}$, Gautier $\mathrm{R}$, Abourachid $\mathrm{H}$, et al. Rat colonic carcinogenesis after ureterosigmoidostomy: Pathogenesis and immunohistological study. J Urol 1988;139:1331-6.

19. Deutz FJ, Rubben $\mathrm{H}$, Kupper $W$, et al. Morphological changes of urothelial and intestinal mucosa after ureterosigmoidostomy during experimental urogenic carcinogenesis. Urol Res 1989;17:223-7.

20. Yura $Y$, Hayashi 0 , Kelly $M$, et al. Identification of epidermal growth factor as a component of the rat urinary bladder tumor-enhancing urinary fractions. Cancer Res 1989;49:1548-53.

Correspondence: Dr. Wassim Kassouf, Montreal General Hospital L8-309, 1650, Cedar Ave., Montreal, QC H3G 1A4; wassim.kassouf@muhc.mcgill.ca 